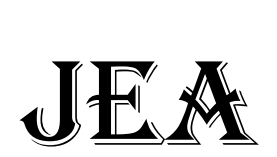

Jurnal Eksplorasi Akuntansi

Vol. 2, No 1, Seri A, Februari 2020, Hal 2035-2050

ISSN : 2656-3649 (Online)

http://jea.ppj.unp.ac.id/index.php/jea/issue/view/17

\title{
PENGARUH STRUKTUR KEPEMILIKAN INSTITUSIONAL, PROFITABILITAS, DAN RESIKO PERUSAHAAN TERHADAP KINERJA INTELLECTUAL CAPITAL
} (Studi Empiris Pada Perusahaan Perbankan yang Terdaftar di Bursa Efek Indonesia Tahun 2015-2018)

\author{
Ade Apriliani ${ }^{1}$, Henri Agustin ${ }^{2}$, Salma Taqwa ${ }^{3}$ \\ ${ }^{1}$ Alumni Jurusan Akuntansi Fakultas Ekonomi Universitas Negeri Padang \\ 2,3Jurusan Akuntansi Fakultas ekonomi Universitas Negeri Padang \\ *Korespondensi: adeapriliani07041994@gmail.com
}

\begin{abstract}
Abstrack: This study aims to determine the effect of institusional ownwership structure, profitability, and company risk. the population in this study were all banking company registered at BEI from 2015-2018. The sample in this study is a total sampling technique, where the entri population is sampled. With a total sample 168 sample using a purposive sampling method. The results of empirical studies show that institutional ownership structure, risk do not affect IC has a positive effect on IC and profitability has a positive effect on IC. Recommendations for further research are expected to conduct research in different business fields such as manufacturing sector companies, real estate companies etc. Adding variables not examined in this study. With company size variables, leverge and other ownership structures.
\end{abstract}

Keywords: institusional ownwership structure, profitability, company risk and performance intellectual capital

How to cite (APA $6^{\text {th }}$ style):

Apriliani, Ade, Henri Agustin \& Salma Taqwa. (2020). Pengaruh Struktur Kepemilikan Institusional, Profitabilitas, dan Resiko Perusahaan terhadap Kinerja Intellectual Capital (Studi Empiris pada Perusahaan Perbankan yang Terdaftar di Bursa Efek Indonesia Tahun 2015-2018). Jurnal Eksplorasi Akuntansi, 2(1), Seri A, 2035-2050.

\section{PENDAHULUAN}

Perekonomian Indonesia saat ini menghadapi berbagai peluang dan tantangan yang kompleks. Mengharuskan setiap pelaku bisnis untuk meningkatkan keunggulan kompetitif dari sumber daya manusia yang dimiliki. Adanya pengakuan luas sumber daya intellectual capital dan hubungan pelanggan menjadi kekuatan pendorong dibalik kesuksesan bisnis di zaman sekarang, seperti pengetahuan ekonomi dan lingkungan bisnis global, dinamis dan kompleks merupakan salah satu bukti terkuat dari peran intellectual capital yang besar antara nilai perusahaan dan nilai buku perusahaan, yang sering dibahas dalam intellectual capital. 
Secara internasional, kajian tentang intellectual capital mulai berkembang tahun 1990-an, akademisi dan praktisi mulai meningkatkan perhatian mereka tentang intellectual capital dengan alasan jika aturan akuntansi tidak beradaptasi dengan meningkatkan kebutuhan informasi yang relevan tentang intellectual capital, maka akuntansi akan kehilangan relevansinya. Di Indonesia intellectual capital sudah diakui serta dibahas dalam Pernyataan Standar Akuntasni Keuangan (PSAK) 19 (revisi 2010) mengenai asset tidak berwujud yang merupakan adopsi dari International Accounting Standard (IAS) 38 tentang itangible asset. Di dalam standar tersebut, intellectual capital tidak disebut secara implisit, namun komponen-komponen intellectual capital (contohnya goodwill) dijabarkan bagaimana perlakuan akuntansinya. Namun, PSAK 19 (revisi 2010) tidak mengatur semua komponen intellectual capital. Sehingga keterbatasan ketentuan standar akuntansi tentang intellectual capital.

Edvinsson dan Sullivan (1996) dalam Al-Musalli (2011) mendefinisikan intellectual capital sebagai pengetahuan yang bisa dikonversi menjadi nilai. Kinerja intellectual capital merupakan gambaran kemampuan perusahaan dalam mengelola dan memaksimalkan intellectual capital yang dimiliki (Ulum 2014). Pengidentifikasian kinerja intellectual capital telah dilakukan oleh beberapa ahli sehingga, terdapat beberapa pendapat tentang komponen intellectual capital. Public (1998) dalam Ulum (2016) komponen utama dari kinerja intellectual capital dilihat dari sumber daya perusahaan seperti physical capital dan human capital. Sedangkan menurut Suwarjono (2003) intellectual capital terdiri dari human capital, structural capital (organization capital) dan relational capital (costumer capital).

Astute (2005) dalam Ulum (2016) menyatakan untuk mencapai nilai intellectual capital yang tinggi, perusahaan harus merubah pola industry mereka dari productivity-based industries menjadi knowledge-based industries. Knowledge-based industries ditandai dengan adanya pola investasi yang tinggi pada research and development, teknologi informasi, pelatihan pegawai dan perekrutan pelanggan. Kepemilikan institusional adalah kepemilikan saham oleh institusi lain, yaitu kepemilikan oleh perusahaan atau lembaga lain seperti asuransi, bank, perusahaan investasi dan lainnya. Dalam beberapa dekade terakhir, dengan adanya konflik keagenan, kehadiran sistem tata kelola perusahaan yang tepat diharapkan dapat membantu perusahaan menyelesaikan konflik keagenan dan menarik perhatian investor serta mendorong mereka untuk berinvestasi dan mengimplementasikan kebijakan untuk mencapai tujuan perusahaan dengan kinerja yang lebih baik. Salah satu control dan tata kelola perusahaan adalah dengan menentukan jenis srtuktur kepemilikan dan komposisi optimalnya

Profitabilitas merupakan suatu rasio keuangan yang juga sangat diperlukan oleh investor dalam jangka panjang dalam menganalisis keuntungan yang akan diterima dalam bentuk deviden. Profitabilitas mengambarkan kemampuan perusahaan mendapatkan keuntungan dengan menggunakan modal fisik, modal finansial dan modal pengetahuan (inovasi, kreativitas, penguasaan teknologi dan informasi) dalam menghasilkan produknya. Resiko perusahaan adalah suatu kondisi dimana kemungkinan-kemungkinan yang menyebabkan kinerja suatu perusahaan menjadi lebih rendah dari pada apa yang diharapkan suatu perusahaan karena adanya suatu kondisi tertentu yang tidak pasti di masa mendatang.

Fenomena yang terjadi di Indonesia pada saat ini adalah rendahnya tingkat daya saing pada kualitas sumber daya manusia seperti, lemahnya penguasaan teknologi sehingga kurang memiliki keunggulan kompetitif dalam persaingan bisnis global. Hal ini sesuai dengan laporan yang dikeluarkan World Economic Forum (WEF) pada oktober 2018 dengan sejumlah komponen yang diteliti dalam WEF antara lain institusi, infrastruktur, kesiapan (penguasaan) teknologi informasi dan komunikasi, stabilitas makro ekonomi, kesehatan, keterampilan SDM, 
pangsa pasar, pasar tenaga kerja, sistem keuangan, dinamika bisnis, hingga kapasitas inovasi. Dimana tingkat daya saing SDM Indonesia pada tahun 2018 berada di posisi 45 dunia. Pada tahun 2014 Indonesia berada pada posisi 37 di dunia, pada tahun 2015-2016 berada pada posisi 67.

Ekonom Maybank Myrdal Gunanto menyebutkan dalam Kontan.co.id terdapat beberapa masalah yang harus diperhatikan mulai dari pengaruh global hingga masalah sumber daya manusia di dalam negeri (kualitas pendidikan dan kemampuan sumber daya manusia). Fenomena diatas mengindikasikan bahwa hingga saat ini intellectual capital belum diterapkan secara maksimal sehingga menyebabkan rendahnya daya saing perusahaan dalam persaingan global. Berdasarkan penuturan diatas bisa saja disebabkan oleh struktur kepemilikan institusional, profitabilitas dan resiko perusahaan yang menentukan tingkat keberhasilan kinerja intellectual capital. Hal inilah yang memicu penulis untuk mengambil kinerja intellectual capital untuk di teliti kembali.

Beberapa penelitian sejenis yang telah dilakukan oleh peneliti-peneliti sebelumnya diantaranya Supradnya dan I Gusti (2016) yang menemukan bahwa kepemilikan institusional berpengaruh positif terhadap kinerja intellectual capital, Kemudian Zanjirdar (2011) menemukan bahwa kepemilikan institusional berpengaruh negatif terhadap kinerja intellectual capital. Berikutnya El- Bannany (2008) menemukan bahwa profitabilitas mempunyai hubungan positif terhadap kinerja intellectual capital. Konsinsten dengan penelitian yang dilakukan oleh Widaryanti (2011) tentang faktor-faktor yang mempengaruhi kinerja intellectual capital pada industri perbankan yang listing di bursa efek Indonesia. Menyatakan bahwa profitabilitas terbukti berpengaruh positif terhadap kinerja intellectual capital. Hasil penelitian El-Bannany (2008) salah satu variabel penelitiannya resiko perusahaan berpengaruh positif terhadap kinerja intellectual capital.

Menurut Chan (2009), ada 34 metode yang mendukung dalam literatur untuk mengukur intellectual capital. Di antara metode ini, nilai tambah koefisien intelektual (VAIC) disarankan sebagai metode yang paling tepat untuk mengukur kinerja intellectual capital dari organisasi manapun (Kamath, 2007; Zeghal dan Maaloul, 2010; Joshi et al., 2010). Penelitian ini dilakukan pada perusahaan perbankan karena industri perbankan adalah industri yang padat pengetahuan, yang membutuhkan sumber daya manusia dan didukung dengan aset intellectual. Dimana aset ini lebih penting dari modal fisik (Al-Bannany, 2008; Kamath, 2007; Goh, 2005).

Tujuan dari penelitian ini adalah untuk memberikan bukti empiris mengenai pengaruh struktur kepemilikan institusional, profitabilitas, dan resiko perusahaan terhadap kinerja intellectual capital. Adapun manfaat untuk penelitian ini yaitu, bagi peneliti untuk menerapkan ilmu yang didapat serta melatih proses berfikir secara ilmiah. Untuk akademisi untuk menambah wawasan ilmu bagi dunia akdemik mengenai pengaruh struktur kepemilikan institusional, profitabilitas, dan resiko perusahaan terhadap kinerja intellectual capital, serta untuk perusahaan penelitian ini dapat menjadi masukan bagi perusahaan dalam meningkatkan kinerja intellectual capital.

\section{REVIEW LITERATUR DAN PENGEMBANGAN HIPOTESIS Resources-Based Theory (RBT)}

Resources-Based Theory menyatakan dengan menganalisis dan menginterprestasikan sumber daya, perusahaan dapat memahami bagaimana suatu perusahaan akan mencapai keunggulan kompetitifnya dengan meyakini bahwa perusahaan akan mencapai tujuannya apabila memiliki sumber daya yang unggul. Resources-Based Theory yang di pelopori Penrose (1959) 
dalam Ulum (2016) Ada dua asumsi yang melekat pada RBT (Nothnagel, 2008), yaitu resource heterogeneity dan resource immobility. Resource heterogeneity (juga disebut resource divercity) menyinggung apakah sebuah perusahaan memiliki sumber daya atau kapabilitas yang juga dimiliki oleh perusahaan lain yang menjadi kompetitornya, sehingga sumber daya tersebut dianggap tidak dapat menjadi suatu keunggulan bersaing. Sedangkan resource immobility menunjuk pada sumber daya yang sulit didapat oleh kompetitor karena sulit untuk mendapatkan atau jika menggunakan sumber saya tersebut biayanya sangat mahal.

\section{Intellectual Capital}

Intellectual capital umumnya didefinisikan sebagai perbedaan antara nilai pasar perusahaan dan nilai buku dari asset perusahaan atau financial capitalnya (Roslender \& Fincham, 2004 dalam Ulum, 2009).Stewart (1997) dalam Ulum (2016) mendefinisikan intellectual capital sebagai jumlah dari segala sesuatu yang ada di perusahaan yang dapat membantu perusahaan untuk berkompetisi di pasar, meliputi intellectual material - pengetahuan, informsasi, pengalaman, dan intellectual property yang digunakan untuk menciptakan kesejahteraan. Brooking (1996) dalam Ulum (2016) menyatakan bahwa intellectual capital adalah istilah yang diberikan kepada kombinasi dari asset tidak berwujud, property perusahaan untuk dapat berfungsi. Dari beberapa pengertian diatas maka dapat disimpulkan bahwa intellectual capital adalah segala sesuatu yang ada pada perusahaan berupa pengetahuan, pengalaman, informasi, dan inovasi untuk meningkatkan keunggulan kompetitif sehingga bisa mencapai tujuan perusahaan.

\section{Komponen Intellectual Capital}

OECD (2000) menghasilkan klasifikasi IC menjadi dua komponen: modal manusia dan modal struktural. Sumber daya manusia (HC) didefinisikan sebagai pengetahuan, kualifikasi, pengalaman, dan keahlian yang mereka bawa saat mereka mereka meninggalkan perusahaan (Roos dan Roos, 1997; Zeghal dan Maaloul, 2010). Pengetahuan karyawan Unggul untuk individu atau generik seperti Kemampuan, Kreativitas, kecakapan dan pengalaman sebelumnya, kemampuan kerja, persetujuan karyawan, motivasi, kepuasan, kapasitas belajar, loyalitas, pelatihan formal dan pendidikan (Ting dan Lean, 2009).

Selain klasifikasi ini, ada juga klasifikasi lain yang mengklasifikasikan IC menjadi tiga komponen: modal manusia, modal struktural, dan modal relasional (Kamath, 2007). Klasifikasi terakhir yang merupakan klasifikasi IC yang paling banyak digunakan mengklasifikasikan modal struktural yang dikeluarkan sebelumnya menjadi modal struktural dan modal relasional. Modal relasional pada pengetahuan saluran pasar, hubungan eksternal tegas dengan pelanggan, pemasok, citra dan perusahaan, kepuasan dan loyalitas pelanggan.

\section{Factor Pemicu Intellectual Capital}

Seperti yang dikemukakan Widyaningdyah dan Aryani (2014) suatu perusahaan dikatakan mempunyai keunggulan kompetitif jika bisa menciptakan nilai ekonomis yang lebih tinggi dibandingkan denga perusahaan lainnya. Fokus dunia bisnis tidak lagi pada aset berwujud namun sudah beralih pada ke aset tidak berwujud.

\section{Pengukuran Intellectual Capital}

Value Added Intellectual Coefficient (VAIC) adalah metode nilai tambah intellectual capital yang dikembangkan oleh Public (1998) dalam Ulum (2016) banyak digunakan dalam studi kinerja intellectual capital. Metode ini sangat penting karena memungkinkan perusahaan untuk 
mengukur kontribusi asset berwujud (fisik dan finansial) dan intellectual (manusia) untuk menciptakan nilai tambah (VA) oleh perusahaan. Menurut Chan (2009), ada 34 metode yang mendukung literature untuk mengukur kinerja intellectual capital. Diantara metode ini, nilai tambah koefisien intellectual (VAIC) disarankan sebagai metode yang paling tepat untuk mengukur kinerja intellectual capital dari organisasi manapun (Kamath 2015).

\section{Problematika}

Untuk mengeksplorasi nilai yang tampak dari laporan keuangan (Francis dan Schipper 1999 dalam Ulum 2016) mencatat bahwa selama periode 1977-2001, rasio market-to-book US Standard and poors (S\&P) 500 meningkat di atas 1 sampai lebih dari 5, hal ini menyiratkan bahwa sekitar $80 \%$ dari nilai pasar perusahaan belum tercemin dalam laporan keuangan. Jika perusahaan memiliki intellectual capital dan mengelolanya dengan baik, akan berdampak pada nilai pasar perusahaan. Dengan kata lain, jika pasar modalnya efisien, investor akan memberikan nilai yang lebih tinggi bagi perusahaan dengan nilai intellectual capital yang lebih besar (Riahi 2003 dalam Ulum 2016). Selain itu, jika intellectual capital merupakan sumber daya yang berharga untuk keunggulan kompetitif maka ia akan berkontribusi terhadap kinerja keuangan perusahaan (Kehelwalatenna 2010 dalam Ulum 2016). Keterbatasan laporan keuangan dalam menjelaskan nilai perusahaan menggaris bawahi fakta bahwa sumber nilai ekonomi tidak lagi pada produksi barang-barang material, tetapi penciptaan modal intellectual.

\section{Kepemilikan Institusional}

Kepemilikan institusional adalah kepemilikan saham oleh institusi lain, yaitu kepemilikan oleh perusahaan atau lembaga lain. Kepemilikan saham oleh pihak-pihak yang terbentuk institusi seperti perusahaan asuransi, bank, perusahaan investasi dan kepemilikan institusi lain.Menurut Nabela (2012) kepemilikan institusional merupakan proporsi saham yang dimiliki pada akhir tahun yang diukur dengan persentase. Sedangkan menurut Nuraina (2012) kepemilikan institusional adalah persentase saham yang dimiliki oleh institusi atau lembaga (perusahaan asuransi, dana pensiunan, dan perusahaan lainnya). Jadi, dapat di simpulkan bahwa kepemilikan institusional adalah kepemilikan saham yang dimiliki pihak institusi seperti lembaga asunransi, dana pensiunan, dan lembaga lainnya diukur dengan persentase yang diukur setiap akhir tahun.

\section{Pengukuran Kepemilikan Institusional}

Struktur kepemilikan isntitusional diukur dari persentase kepemilikan saham yang dimiliki pihak institusional.

$$
\text { Kepemilikan Institusional }=\frac{\text { Kepemilikan Saham Institusional }}{\text { Seluruh Kepemilikan Saham }} \times 100 \%
$$

\section{Profitabilitas}

Profitabilitas merupakan suatu rasio keuangan yang juga sangat diperlukan oleh investor dalam jangka panjang dalam menganalisis keuntungan yang akan diterima dalam bentuk deviden (Saleh, 2008). Profitabilitas merupakan salah satu cara untuk mengukur kinerja perusahaan. Pengukuran kinerja perusahaan dengan cara ini dapat memotivasi karyawan dalam mencapai sasaran organisasi dan dalam mematuhi standar perilaku yang telah ditetapkan sebelumnya agar menghasilkan tindakan dan hasil yang diinginkan (Lina, 2013).

$$
\text { Return on Assets }(\text { ROA })=\frac{\text { Laba Bersih }}{\text { Total Asset }} \quad \ldots(\text { Subramanyam 2010) }
$$




\section{Resiko Perusahaan}

Resiko perusahaan adalah suatu kondisi dimana kemungkinan-kemungkinan yang menyebabkan kinerja suatu perusahaan menjadi lebih rendah dari pada apa yang diharapkan suatu perusahaan karena adanya suatu kondisi tertentu yang tidak pasti di masa mendatang. Oleh karena itu dengan memahami resiko yang ada perusahaan mampu mencegah resiko tersebut dengan mengidentifikasi dan menstabilkan kinerja meraka, sehingga mampu untuk memenuhi target, meminimalisir kegagalan dalam perusahaan dan mampu menciptan sebuah peluang bisnis yang menguntungkan.

$$
\frac{\text { Total NPL }}{\text { Total Kredit }} \times 100 \%
$$

\section{KERANGKA KONSEPTUAL}

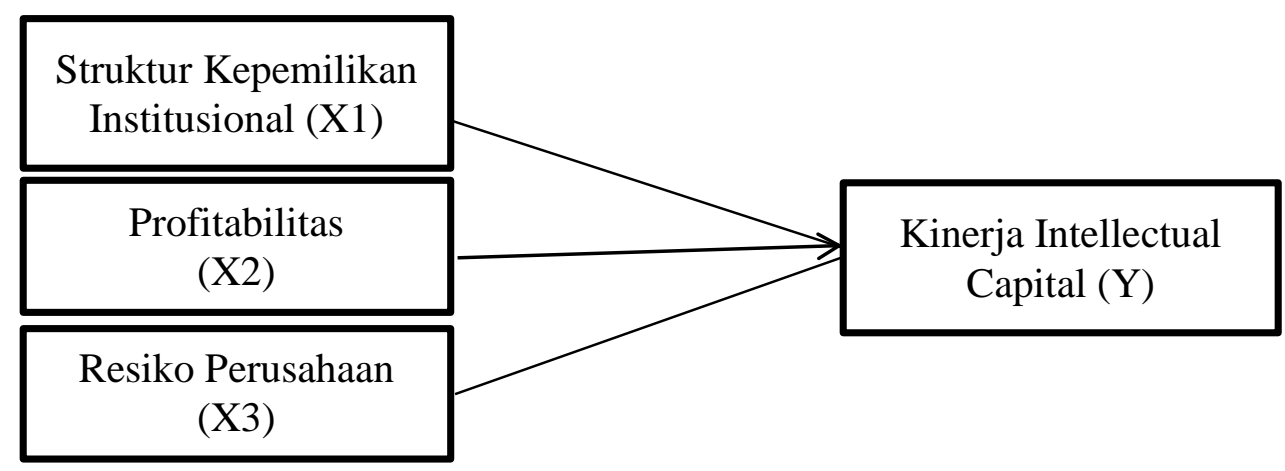

\section{Pengaruh Kepemilikan Institusional dan Kinerja Intellectual Capital}

Kepemilikan institusional merupakan mekanisme yang dapat digunakan untuk mengurangi masalah keagenan selain meningkatkan kepemilikan manajerial. Peningkatan kepemilikan institusional membuat pengawasan yang lebih terhadap perilaku oportunistik manajer. Sehingga manajer bertindak sesuai dengan keinginan investor. (Bathala et.al., 1999 dalam Novitasari, 2009). The efficiency Argumentation et. Al (2005) dalam the $2^{\text {nd }}$ National Conference UKWMS (2008) dalam Novitasari (2009) menyatakan bahwa orientasi investasi jangka panjang berupa deviden, sehingga investor institusional akan lebih memilih dan mendukung kebijakan peningkatan dan pengelolaan intellectual capital.

Peningkatan nilai perusahan dipengaruhi oleh kemampuan perusahaan dalam melakukan investasi yang menguntungkan. Ketersediaan dana dalam perusahaan akan mempengaruhi Implementasi keputusan investasi (internal financing) dan sumber pendanaan eksternal (external financing). Dengan memperhatikan sumber-sumber pembiayaan, perusahaan memiliki beberapa alternative pembiayaan untuk menentukan struktur modal yang tepat bagi perusahaan. Secara umum investor menilai laba yang tinggi menunjukan prospek yang baik di masa depan. Tingginya laba menunjukkan efektifitas dan efisiensi dalam pengelolaan perusahaan. Peningkatan nilai perusahan dipengaruhi oleh kemampuan perusahaan dalam melakukan investasi yang menguntungkan.

H1: kepemilikan institusional berpengaruh positif terhadap kinerja intellectual capital

\section{Pengaruh Profitabilitas dan Kinerja Intellectual Capital}

Menurut PSAK Nomor 1, informasi laba diperlukan untuk menilai perubahan potensi sumber daya ekonomis yang dapat dikendalikan di masa depan, untuk menghasilkan arus kas dari 
sumber daya yang dimiliki, dan untuk perumusan pertimbangan tentang efektivitas perusahaan dan pemanfaatan tambahan sumberdaya. Menurut teori Resource Based Theory, dengan intellectual capital yang dimiliki membuat perusahaan mampu memaksimalkan penggunaan sumber daya dengan efisien dan ekonomis. Ketika profitabilitas perusahaan meningkat, hal itu menunjukkan bahwa perusahaan telah menggunakan asetnta secara efektif.

Sehingga menghasilkan produk yang unggul dalam persaingan dan diharapkan dapat meningkatkan penjualan. Hai ini nantinya berdampak pada tingkat pengembalian dana dalam bentuk kas yang diperoleh oleh perusahaan berdasarkan efektifitas penggunaan asset, sehingga dapat menciptakan value added. Sesuai dengan Resource Based Theory dimana perusahaan yang mampu mengelola intellectual capital dengan baik maka perusahaan tersebut akan memiliki keunggulan kompetitif sserta diyakini mampu menciptakan nilai tambah yang berpengaruh terhadap peningkatan kinerja keuangan perusahaan.

H2: Profitabilitas berpengaruh positif terhadap kinerja intellectual capital

\section{Pengaruh Resiko Perusahaan dan Kinerja Intellectual Capital}

El-Bannary, (2008) menyatakan adanya hubungan yang positif antara risiko dan tingkat pengembalian. Ketika perusahaan dapat meminimalisis terjadinya resiko maka perusahaan tersebut telah menggunakan asset nya secara efektif dan efisien. Sehingga kerugian yang di terima perusahaanpun berkurang, hal ini tentunya berpengaruh terhadap laba yang di terima perusahaan. Tingkat laba yang meningkat akan membuat manajemen tidak lagi berfokus pada penciptaan dan poemeliharaan intellectual capital yang diyakini dapat menciptakan keunggulan kompetitif dalam jangka panjang

H3: resiko perusahaan berpengaruh positif terhadap kinerja Intellectual capital

\section{METODE PENELITIAN}

Berdasarkan rumusan masalah dan tujuan yang telah dikemukakan di atas, maka penelitian ini tergolong penelitian kausatif. Populsi dari penelitian ini adalah perusahaan perbankan yang terdaftar di Bursa Efek Indonesia pada tahun 2015-2018dengan periode pengamatan tahun 20152018. Jumlah perusahaan perbankan yang terdaftar di Bursa Efek Indonesia sampai tahun 2019 adalah 45 bank. Sampel atau contoh merupakan sebagian dari populasi yang karakteristiknya hendak diteliti. Penentuan sample ditetapkan dengan teknik total sampling, yakni seluruh populasi dijadikan sample. Pada study empiris ini menggunakan data sekunder yang bersumber dari perusahaan perbankan yang terdaftar di BEI selama periode 2015-2018 yang diperoleh dari www.idx.co.id.

\section{VARIABEL PENELITIAN DAN PENGUKURAN VARIABEL}

\section{Kinerja Intellectual Capital (Y)}

Kinerja intellectual capital merupakan gambaran kemampuan perusahaan dalam mengelola dan memaksimalkan intellectual capital yang dimiliki.

\section{Value Added Capital Coefficient (VACA)}

VAIC menyajikan informasi mengenai value creation efficiency dari aset fisik dan aset non fisik yang ada pada perusahaan. model ini dimulai dengan kemampuan perusahaan untuk menciptakan value (VA)

$$
\text { VACA }=\frac{\text { Value Added }}{\text { Employeed Capital }} \ldots . .(\text { Ulum 2016) }
$$




\section{Human Capital Coefficient (VAHU)}

Value added human capital menggambarkan berapa nilai dapat dihasilkan dengan modal yang dikeluarkan untuk tenaga kerja. Hubungan ini menggambarkan kemampuan human capital dalam menciptakan nilai untuk perusahaan.

$$
\text { VAHU }=\frac{\text { Value Added }}{\text { Human Capital }} \ldots . \text { (Ulum 2016) }
$$

\section{Structural Capital Coefficient (STVA)}

Hubungan selanjutnya adalah antara structural capital dan value added. Structural capital diperoleh dengan cara selisih antara VA dengan HC. Sedangkan structural capital coefficient didapat dari rasio SC dan VA.

$$
\text { STVA }=\frac{\text { Structural Capital }}{\text { Value Added }} \ldots(\text { Ulum 2016) }
$$

\section{Struktur Kepemilikan Institusional (X1)}

Kepemilikan Institusional pada suatu perusahaan dapat diukur dari persentase kepemilikan saham yang dimiliki pihak Institusional. Perhitungannya adalah.

$$
\text { Kepemilikan Institusional }=\frac{\text { Kepemilikan Saham Institusional }}{\text { Seluruh Kepemilikan Saham }} X 100 \%
$$

\section{Profitabilitas (X2)}

ROA adalah perbandingan laba setelah pajak terhadap total asset. ROA mengindikasikan seberapa besar kemampuan asset yang dimiliki untuk mengahsilkan tingkat penegembalian atau pendapatan atau dengan kata lain ROA menunjukkan kemampuan total asset dalam menghasilkan laba. ROA dapat dihitung dengan rumus sebagai berikut:

$$
\frac{\text { Laba Bersih }}{\text { Total Asset }} \text { (Subramanyam 2010) }
$$

\section{Resiko Perusahaan}

Resiko perusahaan adalah suatu kondisi dimana kemungkinan-kemungkinan yang menyebabkan kinerja suatu perusahaan menjadi lebih rendah dari pada apa yang diharapkan suatu perusahaan karena adanya suatu kondisi tertentu yang tidak pasti di masa mendatang.. Dalam penelitian ini yang digunakan untuk mengukur resiko perusahaan adalah:

$$
\frac{\text { total kredit macet }}{\text { Total kredit }} \times 100 \%
$$

\section{HASIL DAN PEMBAHASAN Analisis Regresi Data Panel}

Regersi data panel merupakan gabungan antara data cross section dan data time series. Tidak seperti regresi data biasanya, data panel harus melalui tahapan penentuan model estimasi yang tepat. Berikut tahapan penentuan estimasi yang akan digunakan sebagai berikut: 


\section{Uji Chow}

\section{Tabel 1 \\ Data Hasil Uji Chow-Test}

Redundant Fixed Effects Tests

Equation: Untitled

Test cross-section fixed effects

\begin{tabular}{lrrr}
\hline Effects Test & Statistic & d.f. & Prob. \\
\hline Cross-section F & & & \\
Cross-section Chi-square & 1.912542 & $(32,95)$ & 0.0084 \\
& 65.142225 & 32 & 0.0005
\end{tabular}

Sumber: data yang diolah dengan eviews 92019

Berdasarkan hasil uji diatas dengan menggunakan program eviews 9, probabilitasnya sebesar 0,0084 , nilai ini lebih kecil dari $(\alpha=0,05)$, maka estimasi yang lebih baik digunakan adalah Fixed Effect. Ketika model yangterpilih adalah Fixed Effect maka perlu dilakukan uji lagi yaitu Uji Hausman.

\section{Uji Hausman}

Berdasarkan hasil model hausman-test, nilai probabilitasnya $0,0102<0,05$. Sehingga estimasi yang lebih baik dalam model ini adalah Fixed Effect.

Tabel 2

Data Hasil Uji Hausman-Test

\section{Correlated Random Effects - Hausman Test}

Equation: Untitled

Test cross-section random effects

\begin{tabular}{lccr}
\hline Test Summary & Chi-Sq. Statistic & Chi-Sq. d.f. & Prob. \\
\hline Cross-section random & & & \\
& 11.300255 & 3 & 0.0102 \\
\hline
\end{tabular}

Sumber: data yang diolah dengan eviews 92019

Berdasarkan hasil model hausman-test, nilai probabilitasnya $0,0102<0,05$. Sehingga estimasi yang lebih baik dalam model ini adalah Fixed Effect.

\section{Uji Asumsi Klasik}

\section{Uji Normalitas}

Pada tabel 3 dapat dilihat nilai probabilitasnya adalah $0,000<$ dari $\alpha(0,05)$ maka residual data belum terdistribusikan dengan normal. Gusarati (2007) menyatakan bahwa asumsi normalitas 
mungkin tidak terlalu penting dalam set data yang besar, yaitu data yang lebih dari 30. Sehingga asumsi normalitas dalam penelitian ini tidak dipermasalahkan.

Tabel 3

Hasil Uji Normalitas Residual
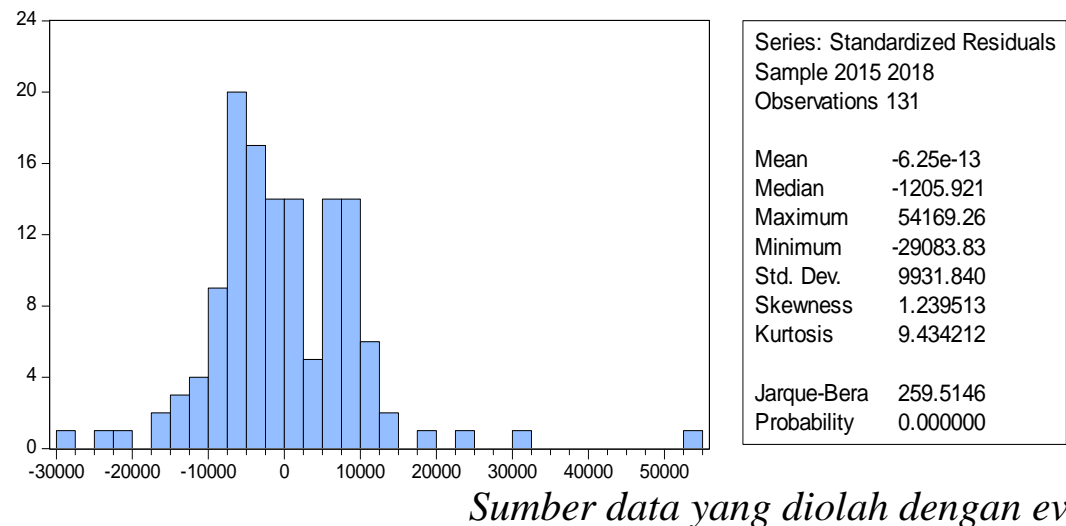

Sumber data yang diolah dengan eviews 92019

\section{Uji Multikolinearitas}

Pada tabel 4 dapat terlihat bahwa seluruh variable bebas memiki nilai korelasi $<0,8$ maka dapat disimpulkan variabel-variabel penelitian tidak memiliki masalah kolonearitas.

Tabel 4

Hasil Uji Multikolinearitas

\begin{tabular}{cccc}
\hline & $\mathrm{X} 1$ & $\mathrm{X} 2$ & $\mathrm{X} 3$ \\
\hline $\mathrm{X} 1$ & 1 & -0.04947382690801612 & 0.1170422280650388 \\
$\mathrm{X} 2$ & -0.04947382690801612 & 1 & 0.00349209961629346 \\
$\mathrm{X} 3$ & 0.1170422280650388 & 0.00349209961629346 & 1 \\
\hline \multicolumn{2}{l}{ Sumber data yang diolah dengan eviews } & 92019.
\end{tabular}

\section{Uji Autokorelasi}

Pada tabel dapat dilihat nilai Durbin-Watson stat adalah 2,640139 dimana k= 34 dan $\mathrm{N}=136$. Dengan $d l$ 1,2707 dan $d u$ 1,6519. Nilai dw pada analisis ini lebih dari nilai $d l$ dan $d u$ maka terdapat gejala autokorelasi yang negatif.

Tabel 5

\section{Hasil Uji Aoutokorelasi}

Cross-section fixed (dummy variables)

\begin{tabular}{lclr}
\hline R-squared & 0.603893 & Mean dependent var & 22608.36 \\
\hline Adjusted R-squared & 0.457959 & S.D. dependent var & 12306.73 \\
S.E. of regression & 9060.643 & Akaike info criterion & 21.28957 \\
Sum squared resid & $7.80 \mathrm{E}+09$ & Schwarz criterion & 22.07970
\end{tabular}




$\begin{array}{lrlr}\text { Log likelihood } & -1358.467 & \text { Hannan-Quinn criter. } & 21.61063 \\ \text { F-statistic } & 4.138116 & \text { Durbin-Watson stat } & 2.640139 \\ \text { Prob(F-statistic) } & 0.000000 & & \end{array}$

Sumber data yang diolah dengan eviews 92019

\section{Uji Heterokedastisitas}

Berdasarkan tabel 4.5 dapat dilihat bahwa probabilitas veariabel-variabel yang diteliti $>\alpha(0,05)$, maka dapat disimpulkan tidak ada gejala heterokedastisitas.

\section{Tabel 6 \\ Hasil Uji Heterokedastisitas}

Dependent Variable: RESABS

Method: Panel Least Squares

Date: 01/21/20 Time: 17:32

Sample: 20152018

Periods included: 4

Cross-sections included: 33

Total panel (unbalanced) observations: 131

\begin{tabular}{crrrr}
\hline Variable & Coefficient & Std. Error & t-Statistic & Prob. \\
\hline C & 3697.197 & 1525.789 & 2.423137 & 0.0168 \\
X1 & 0.155111 & 0.203820 & 0.761022 & 0.4481 \\
X2 & -3.173113 & 2.965768 & -1.069913 & 0.2867 \\
X3 & 1.287000 & 2.112665 & 0.609183 & 0.5435 \\
\hline
\end{tabular}

Sumber data yang diolah dengan eviews 92019

\section{Model Regresi Data Panel}

Analisis model regresi data panel berguna untuk melihat pengaruh variabel bebas dan variaber terikat dalam bentuk data runtun waktu (time series) dan runtut tempat (cross section)

\section{Tabel 7 \\ Regresi Data Panel Model Fixed Effect}

Dependent Variable: Y

Method: Panel Least Squares

Date: 01/01/80 Time: 01:37

Sample: 20152018

Periods included: 4

Cross-sections included: 33

Total panel (unbalanced) observations: 131 


\begin{tabular}{ccccc}
\hline Variable & Coefficient & Std. Error & t-Statistic & Prob. \\
\hline & & & & \\
C & 24008.77 & 10155.15 & 2.364197 & 0.0201 \\
X1 & -0.710424 & 1.562521 & -0.454666 & 0.6504 \\
X2 & 22.58113 & 6.456181 & 3.497599 & 0.0007 \\
X3 & 3.277917 & 4.614955 & 0.710281 & 0.4793 \\
\hline
\end{tabular}

Effects Specification

Cross-section fixed (dummy variables)

\begin{tabular}{lcll}
\hline R-squared & 0.603893 & Mean dependent var & 22608.36 \\
\hline Adjusted R-squared & 0.457959 & S.D. dependent var & 12306.73 \\
S.E. of regression & 9060.643 & Akaike info criterion & 21.28957 \\
Sum squared resid & $7.80 \mathrm{E}+09$ & Schwarz criterion & 22.07970 \\
Log likelihood & -1358.467 & Hannan-Quinn criter. & 21.61063 \\
F-statistic & 4.138116 & Durbin-Watson stat & 2.640139 \\
Prob(F-statistic) & 0.000000 & & \\
\hline Sumber data diolah dengan
\end{tabular}

Sumber data diolah dengan eviews 92019

\section{Analisis Regresi Fixed}

Analisis data untuk pengujian hipotesis dengan menggunakan analisis regresi panel. Dari pengolahan data statistik diatas, maka diperoleh persamaan sebagai berikut:

$$
V_{A I C^{T M}}=24008,77-0,71(\text { INST })+22,58(\mathrm{ROA})+3,28(\text { IT AGASS })
$$

Berikut penjelasan angka-angka di atas:

\section{Konstanta $(\alpha)$}

Nilai konstanta pada hasil pengujian ini dapat dilihat pada tabel 4.7. Dimana nilai konstanta yang diperoleh sebesar 24008,77 ini artinya jika variabel struktur kepemilikan institusional (X1), profitabilitas (X2), dan resiko perusahaan (X3) bernilai nol (0) maka kinerja intellectual capital akan mengalami kenaikan sebesar 24008,77.

\section{Koefisien Regresi $\left(\beta_{1}\right)$ X1}

Pada tabel 4.7 dapat dilihat nilai koefisien regresi struktur kepemilikan institusional (X1) sebesar $-0,71$ ini menandakan bahwa setiap penambahan satu satuan saham institusional akan meningkatkan kinerja intellectual capital sebesar -0,71.

\section{Koefisien Regresi $\left(\boldsymbol{\beta}_{2}\right) \mathrm{X} 2$}

Pada tabel 4.7 dapat dilihat nilai koefisien regresi profitabilitas (X2), sebesar 22,58 ini menandakan bahwa setiap penambahan satu satuan profitabilitas akan meningkatkan kinerja intellectual capital sebesar 22,58. 


\section{Koefisien Regresi $\left(\boldsymbol{\beta}_{3}\right) \mathrm{X3}$}

Pada tabel 4.7 dapat dilihat nilai koefisien regresi resiko perusahaan (X3) sebesar 3,28 ini menandakan bahwa setiap penambahan satu satuan resiko perusahaan akan meningkatkan kinerja intellectual capital sebesar 3,28.

\section{Adjusted $\boldsymbol{R}^{2}$}

Uji ini digunakan untuk melihat seberapa besar kontribusi pengaruh yang diberikan variabel $\mathrm{X}$ secara silmultan (bersama-sama) terhadap variabel Y. Hasil estimasi diatas dapat dilihat pada tabel 4.7 dimana nilai $R^{2}$ sebesar 60,39\%, artinya sumbangan variabel X1, X2, X3 terhadap Y sebesar 60,39\%. Sedangkan sisanya sebesar 39,61\% dipengaruhi oleh variabel lainnya.

\section{Uji t- Test (Hipotesis)}

Hipotesis pertama dalam penelitian ini adalah struktur kepemilikan institusional berpengaruh positif terhadap kinerja intellectual capital. Dari tabel diatas dapat dilihat bahwa struktur kepemilikan institusional memiliki nilai profitability 0,6504 >0,05. artinya struktur kepemilikan institusional tidak berpengaruh terhadap kinerja intellectual capital. Hipotesis kedua dalam penelitian ini adalah profitabilitas berpengaruh positif terhadap kinerja intellectual capital. Dari tabel diatas dapat dilihat bahwa profitabilitas memiliki nilai profitability 0,0007 $>0,05$. profitabilitas berpengaruh terhadap kinerja intellectual capital. Hipotesis ketiga dalam penelitian ini adalah resiko perusahaan berpengaruh positif terhadap kinerja intellectual capital. Dari tabel diatas dapat dilihat bahwa resiko perusahaan memiliki nilai profitability 0,4793>0,05. profitabilitas tidak berpengaruh terhadap kinerja intellectual capital.

\section{Pembahasan \\ Pengaruh Struktur Kepemilikan Institusional Terhadap Kinerja Intellectual Capital}

Penelitian ini menemukan bukti empiris bahwa struktur kepemilikan institusional tidak berpengaruh terhadap kinerja intellectual capital dengan arah negatif. Artinya struktur kepemilikan institusional tidak memberikan dampak positif terhadap peningkatan kinerja intellectual capital. Dengan demikian temuan penelitian ini bertolak belakang dengan riset terdahulu yang dilakukan sebelumnya oleh I Gusti (2016) yang justru menemukan bahwa kepemilikan institusional berpengaruh positif terhadap kinerja intellectual capital. Implikasi dalam penelitian ini menunjukkan bahwa kepemilikan institusional tidak berpengaruh terhadap kinerja intellectual capital dengan arah negatif.

Kepemilikan institusional tidak menjamin bisa memonitoring penuh kinerja manajer dengan maksimal. Perusahaan dengan tingkat kepemilikan institusional yang tinggi ini memiliki resiko yang lebih besar, dimana tingkat kerugian yang dialami para pemegang saham lebih tinggi. Hasil temuan penelitian ini konsisten dengan riset yang dilakukan oleh Zanjirdar (2011) dan Eloking (2014) dimana kepemilikan institusional tidak berpengaruh terhadap kinerja intellectual capital.

\section{Pengaruh Profitabilits Terhadap Kinerja Intellectual Capital}

Penelitian ini menemukan bukti empiris bahwa profitabilitas berpengaruh signifikan positif terhadap kinerja intellectual capital. Artinya profitabilitas memberikan dampak positif terhadap kinerja intellectual capital. Hasil temuan ini konsisten dengan penelitian terdahulu yang dilakukan oleh El- Bannany (2008) dan Widaryanti (2011) yang menyatakan bahwa profitabilitas berpengaruh positif terhadap kinerja intellectual capital. 
Implikasi dalam temuan ini menunjukkan bahwa profitabilitas berpengaruh positif terhadap kinerja intellectual capital. Hal tersebut berarti bahwa apabila profitabilitas meningkat maka nilai perusahaan yang merupakan kinerja intellectual capital juga akan meningkat. Sesuai dengan teori Weston dan Brigham (2001) yang menyatakan bahwa bahwa profitabilitas yang diukur dengan ROA mencerminkan posisi perusahaan yang bagus sehingga nilai pasar tercermin pada harga saham terhadap perusahaan tersebut juga akan bagus. Didukung dengan teori Husnan (2001) menyatakan bahwa semakin baik pertumbuhan perusahaan berarti prospek perusahaan dimasa depan dinilai semakin baik.

Hal ini dikarenakan profitabilitas yang tinggi mampu mendorong perusahaan untuk mewujudkan tujuan yang ingin dicapai. Sehingga akan diperoleh tingkat pengembalian sesuai dengan yang diharapkan, dimana pengembalian dari modal tersedia yang digunakan oleh perusahaan untuk menghasilkan produk dan jasa sehingga menghasilkan keuntungan sebesar $13 \%$ dari perputaraan penggunan modal yang tersedia pada perusahaan. Dalam perusahaan perbankan profitabilitas merupakan gambaran bagaimana perusahaan memanfaatkan modal yang tersedia untuk mengahsilkan laba. Sebagai tolak ukur utama kinerja perusahaan, maka laba juga dapat digunakan untuk mengukur kinerja intellectual capital.

Hal ini dikarenakan perusahaan yang memperoleh profitabilitas yang tinggi membuat manajemen dapat melakukan kegiatan yang berguna bagi perusahaan seperti mendorong karyawan untuk berinovasi dalam penciptaan produk atau jasa baru dalam meningkatkan keuntungan perusahaan tersebut. Keunggulan kompetitif tersebut meningkatkan tingkat keuntungan perushaan itu sendiri, sehingga perusahaan dapat memaksimalkan kinerja intellectual capital yang dimilikinya.

\section{Pengaruh Resiko Perusahaan Terhadap Kinerja Intellectual Capital}

Penelitian ini menemukan bukti empiris bahwa resiko perusahaan tidak berpengaruh terhadap kinerja intellectual capital. Artinya resiko perusahaan tidak memberikan dampak positif terhadap kinerja intellectual capital. Hasil temuan ini bertolak belakang dengan riset terdahulu yang dilalkukan oleh El-Bannany (2008) yang menyatakan bahwa resiko perusahaan berpengaruh positif terhadap kinerja intellectual capital. Implikasi dalam temuan ini menunjukkan bahwa resiko perusahaan tidak berpengaruh terhadap kinerja intellectual capital. Rendahnya resiko yang akan dihadapi perusahaan belum tentu meningkatkan kinerja intellectual capital pada peerusahaan perbankan.

Pada sampel ini perusahaan dapat meminimalisir terjadinya resiko dengan menggunakan asset nya secara efektisf dan efisien. Sehingga kerugian yang di terima perusahaan setiap tahunnya berkurang, membuat manajemen berfokus pada penciptaan dan pemeliharaan intellectual capital hingga dapat menciptakan keunggulan kompetitif dalam jangka panjang.

\section{SIMPULAN, KETERBATASAN, SARAN Kesimpulan}

Kesimpulan yang diperoleh dari penelitian mengenai Pengaruh Struktur Kepemilikan Institusional, Profitabilitas, Dan Resiko Perusahaan Terhadap Kinerja Intellectual Capital adalah sebagai berikut: Struktur kepemilikan institusional tidak berpengaruh dengan arah negatif terhadap kinerja intellectual capital. Profitabilitas berpengaruh positif terhadap kinerja intellectual capital. Resiko perusahaan institusional tidak berpengaruh dengan arah positif terhadap kinerja intellectual capital. 


\section{Keterbatasan Penelitian}

Penelitian ini hanya menggunakan sampel populasi pada perusahaan perbankan, sehingga hasil penelitian ini tidak bisa digunakan untuk megeneralisasi seluruh perusahaan yang terdaftar di BEI.

\section{Saran}

Berikut ini adalah beberapa saran dari penulis untuk peneliti selanjutnya yang berkaitan dengan penelitian: Menambah sampel perusahaan yang lebih banyak dengan bidang usaha yang berbeda seperti perusahaan sector manukfaktur, perusahaan real estate dll. Menambah variabel-variabel yang tidak diteliti dalam penelitian ini. Dengan variabel ukuran perusahaan, leverge dan struktur kepemilikan lainnya. Menambah tahun pengamatan yang digunakan agar sampel yang diteliti lebih banyak, hasil yang lebih akurat dan bisa lebih mencerminkan kondisi sesungguhnya yang terjadi dilapangan.

\section{DAFTAR PUSTAKA}

Al-Musalli, Mahfoudh Abdul Karem, Dkk. (2011). Intellectual Capital Performance Of The National United Arab Emirates Listed Banks. Paper Presented At The 7th Asia-Pacific Management Accounting Association Conference (APMAA), At Shah Alam Convention Centre, Shah Alam, Malaysia, November 2011. https://www.Researchgate.net/publication.

Bontis, Nick. (2005). National Intellectual Capital Index: The Benchmarking of Arab Countries.

El-Bannany, Magdi. (2008). A Study of Determinants of Intellectual Capital Performance in Banks: The UK Case. Journal of Intellectual Capital, 9(3), 487-498

Faisal. (2005). Analisis Agency Costs, Struktur Kepemilikan Dan Mekanisme Corporate Governance. Jurnal Riset Akuntansi Indonesia, 8(2), 175-190.

Husnan, Suad. (2001). Dasar-Dasar Teori Portofolio dan Analisis Sekuritas. Yogyakarta : Unit Penerbit dan Percetakan AMP YKPN.

Kamath, G. Bharathi. (2015). Impact of Intellectual Capital On Financial Performance and Market Valuation of Firms in India. International Letters of Social and Humanistic Sciences Online. 48, 107. www.scipress.com.

Lina. (2013). Factor-Faktor Penentu Pengungkapan Modal Intellectual. Media Riset Akuntansi, $3(1)$.

Mahardika, Eloking Surya Sekar, dkk. (2014). Pengaruh Struktur Kepemilika, Ukuran dan Umur Perusahaan terhadap Kinerja Intellectual Capital. Accounting Analisys journal, 3 http://journal.unnes.ac.id/sju/indeks.php/aaj.

Mavridis, D. G. (2004), The intellectual capital performance of the Japanese banking sector. Journal of Intellectual Capital, 5(1), 92-115.

Makki, Muhammad Abdul dan Suleman Aziz Lodhi. (2008). Impact of Intellectual Capital Efficiency on Profability (A Case Study of Lse25 Companies). The Lahore Journal of Economics.

Nabela, Yoandhika. (2012). Pengaruh Kepemilikan Institusioanl, Kebijakan Dividen, Dan Profitabilitas Terhadap Kebijakan Hutang Pada Perusahaan Properti dan Real Estate Di Bursa Efek Indonesia. Jurnal Manajemen, 1(1).

Novitasari, Tera. (2009). Pengaruh Struktur Kepemilikan terhadap Kinerja Intellectual Capital.

Nuraina, Elva. (2012). Pengaruh Kepemilikan Institusional Dan Ukuran Perusahaan Terhadap Kebijakan Hutang Dan Nilai Perusahaan. Jurnal Bisnis Dan Ekonomi (JBE), 110-125 
Nur, Indrianto dan Bambang Supomo. (2009). Metodologi Peneliltian Bisnis untuk Akuntansi dan Manajemen. Yogyakarta: BOFE-YOGYAKARTA.

Oktaviani, Heni. (2014). Faktor-Faktor yang Mempengaruhi Pengungkapan Intellectual Capital. Jurnal Ilmu dan Riset Akuntansi, 3(5).

Purwanto, Agus. (2011). Pengaruh Struktur Kpemilikan Perusahaan terhadap Intellectual Capital Performancce. Jurnal Prestasi, 8(2)

Rehman, Wasim Ul, dkk. (2012). A Link of Intellectual Capital Performance With Corporate Performance: Comparative Study From Banking Sector In Pakistan. International Journal of Businwess and Social Science, 3(12).

Saham Ok. Indonesia. Tanggal Listing IPO Emiten/ Perusahaan Punlik/ Terbuka BEI. http://.sahamok.com Diakses 2019.

Sawarjuwono, T. dan Kadir, A. P. (2003). Intellectual Capital: Perlakuan, Pengukuran dan Pelaporan (sebuah Library Research). Jurnal Akuntansi dan Keuangan, 5(1), 35-57

Shaleh, Norman Mohd, dkk. (2009). Ownership Structure and Intellectual Capital Performance in Malaysia. Asian Academis of Management Journal of accounting and Finance, 5(1).

Subramanyam. (2010). Analisis Laporan Keuangan. Salemba Empat.

Supradnya, I Nyoman Trisna danI Gusti Ketut Agung Ulupui. (2016). Pengaruh Jenis Industry, Kepemilikan Manajerial, Kepemilikan Institusional, Dan Kepemilikan Asing Terhadap Kinerja Modal Intellectual. E-Jurnal Ekonomi dan Bisnis Universitas Udayana, 5(5).

Ulum, Ihyatul. (2008). Intellectual Capital Sector Perbankan di Indonesia. Jurnal Akuntansi dan Keuangan, 10(2), 77-84.

Ulum, Ihyatul. (2009). Intellectual Capital: Konsep Dan Kajian Empiris. Malang: Graha Ilmu.

Ulum, Ihyatul. (2016). Intellectual Capital: Model Pengukuran, Framework Pengungkapan dan Kinerja Organisasi. Malang: UMM PRES .

Ulum, Ihyatul, dkk. (2016). Intellectual Capital Performancce: A Comparative Study Between Finacial and Non-Financial Industry of Indonesian Biggest Companies. International Journal of Economics and Financial Issues, 6(4), 1436-1439. Issn: 2146-4138. www.ejournals.com.

Villalonga, B., \& Amit, R. (2006). How do family ownership, control and management affect firm value? Journal of Financial Economics

Weston, J. Fred dan Eugene Brigham. (2001). Manajemen Keuangan. Edisi kesembilan. Jakarta: Erlangga.

Widaryanti. (2011). Factor-Faktor Yang Mempengaruhi Kinerja Intellectual Capital Pada Industry Perbnkan Yang Listing di BEI. Journal Fokus Ekonomi, 6(1).

Zanjidan, Majid an Ava Kabiribalajadeh. (2011). Examining Relationship Between Ownership Structure and Performance of Intellectual Capital in the Stock Market of Iran. Indian Journal of Science and technology, 4(10). Issn:0974-6848. 